\title{
The Relationship between Preschoolers' Attachment Representation and Behavior Problems
}

\author{
Jin Suk Lee, Jihyeon Han \\ Department of Child Studies, Chonbuk National University, Jeonju, Korea \\ 유아의 내러티브 애착표상에 따른 문제행동 연구 \\ 이진숙, 한지현 \\ 전북대학교 아동학과
}

Objective: The main purpose of this study is to investigate the differences in preschoolers' problem behaviors according to their types of attachment.

Methods: The subjects of this study were 100 children (42 boys and 58 girls) who were 4-6 years old and were attending childcare center or kindergarten in Jeonbuk J city. The attachment representation of the young children was assessed using the Attachment Story Completion Task (ASCT), which was developed by Bretherton, Ridgeway and Cassidy(1990). Preschoolers' problem behaviors were assessed using the K-CBCL 1.5-5 (Korean Child Behavior Checklist for Ages 1-5-5). Content analysis and type classification were conducted based on various attachment coding manuals. The data were analyzed using Pearson's correlation analysis and $\mathrm{t} / \mathrm{F}$ test.

Results and Conclusion: First, in the secure attachment type, nurturance/empathy, companionship, calm response to separation, and positive affection response codes were high, whereas in the avoidant attachment type, high avoidance response appeared, and in the disorganized attachment type, high bizarre negative event codes and disjointed event codes were found. Second, atypical event scores were positively correlated with aggressive behavior, the externalization of behavior problems, and oppositional defiant behavior problem. Third, it was found that the subscales (aggression and oppositional defiant behavior problem) of the problem behaviors differ according to the attachment type of the preschoolers. In partivular, the insecure-disorganized attachment type showed significantly higher problem behavior scores than did the other attachment types (secure and, avoidant attachment types). This result supports the theory of a relationship between secure attachment and the social-emotional development of preschoolers, and highlights the need for attention to and involvement with preschoolers of the insecure-disorganized attachment type.

Keywords: attachment representation based on narrative method, preschoolers' problem behavior

$$
\text { 서론 }
$$

어린 유아가 어머니에 대해 갖는 정서적 유대는 생애초기에 발달하는 내재적이면서도 독특한 행동양식의 결과로(Bowlby,

Corresponding Author: Jihyeon Han, Department of Child Studies, Chonbuk National University, 567 Baekje-daero, Deokjin-gu, Jeonju-si, Jeollabuk-do, Korea

E-mail: narahan1217@hanmail.net
1980) 어머니에 대해 가능한 한 가까운 근접성을 유지하고 자 하는 형태로 나타난다. 생후 첫해 말이 되면 특정조건, 예 컨대 아이가 고통스럽거나 무서움을 느끼거나 엄마가 근처 가 없다고 인식했을 때 애착행동이 활성화된다. 또한 애착대

(C)The Korean Association of Child Studies

This is an Open Access article distributed under the terms of the Creative Commons Attribution Non-Commercial License (http:// creativecommons.org/licenses/by-nc/4.0) which permits unrestricted noncommercial use, distribution, and reproduction in any medium, provided the original work is properly cited. 
상과의 관계가 어떠한가에 따라 그에 수반되는 정서가 달라 진다. 즉 부모-자녀 간에 긍정적인 관계가 형성된 경우 유아는 기쁨과 안정감을 느끼지만, 그 관계가 위험에 처한 경우에는 불안과 분노 등의 감정이 뒤따르고, 슬픔과 우울을 경험하게 된다(Bowlby, 2014: 19-20). 이처럼 생애 초기에 형성된 주양 육자와의 애착관계는 영유아의 자아감 발달과 사회정서 - 인 지 등 전반적인 발달에 영향을 미치는 요인으로(Bowlby, 1980; Breatherton, 1985) 애착 패턴이 일단 발달하고 나면 전 생애를 통해 지속되는 경향이 있다.

애착과 사회정서 발달과의 관련성은 내적실행모델(internal working model)개념에 의해 설명되고 있다. 내적실행모델이란 세상에서 일어나는 사건들을 지각하고 해석하는 정신적인 틀 로서, 주양육자의 민감하고 일관성있는 반응 여부는 유아의 긍정적 · 부정적인 내적실행모델의 발달과 관련된다. 즉, 주양 육자(부모)의 민감하고 일관성있는 반응을 통해 유아는 긍정 적인 표상을 형성하며 이를 통해 자신을 가치로운 존재로 느 끼는 반면, 부정적 표상을 형성할 경우 타인에 대한 두려움과 불안을 느끼며 사회적 관계에서 위축되고 부정적으로 여기게 된다는 것이다(Bowlby, 1980; Bretherton, 1985). 많은 애착관련 연구들은 생애 초기의 안정적인 애착관계는 정서적 안전기저 가 되어 건강한 성격발달의 기초가 되는 반면, 불안정한 애착 관계는 이후의 심리적 어려움이나 문제행동을 예측하는 요인 이라고 밝혀왔다. 안정애착 유아는 불안정 애착 유아에 비해 인기있고 리더쉽이 있으며 사회적으로 유능한 반면(S. H. Lee \& Kim, 1996; Vershueren, 1999) 불안정 애착 유아는 분노와 공격성 등 외현화 문제행동이 높고 또래관계에 어려움이 있 는 것으로 나타났다(DeMulder, Denham, Schmidt, \& Mitchell, 2000; Shaw, Keenan, Vondra, Delliquadri, \& Giovannelli, 1997; Sroufe, 1983; Sroufe, Schork, Motti, Lawroski, \& LaFreniere, 1984). Sroufe 등(1984)의 연구에서 불안정 애착 유아는 안정애 착 유아에 비해 분노 · 공격성 수준이 높았으며, Shaw 등(1997) 의 연구에서는 안정애착 아동의 $17 \%$ 가 공격성을 보인 반면 불안형 아동의 $30 \%$, 혼란형 아동의 $60 \%$ 가 임상적으로 높은 수준의 공격성을 보고하였다.

애착관련 초기 연구들이 영아를 대상으로 낮선상황실험 (Ainsworth, Blehar, Water, \& Wall, 1978)과 애착 Q-set(Water $\&$ Deane, 1985) 등을 사용하였는데, 언어 - 인지능력이 발 달한 유-아동의 경우 행동평가를 근거한 관찰방법의 한계 가 제기됨에 따라 애착관계에 대한 내적표상을 상징적 표상 을 통해 측정하는 방안이 논의되기 시작했다. 예컨대, Slough 와 Greenberg (1990)의 격리불안검사(Separation Anxiety Test
[SAT]), MacArthur 이야기 꾸미기 도구(MacArthur Story-Stem Battery [MSSB]), Bretherton, Ridgeway와 Cassidy (1990)의 애착 이야기완성과제(Attachment Story Completion Task [ASCT]) 등 과 같은 그림이나 인형놀이를 통한 애착 검사가 개발되면서 취학 전 유아와 아동을 대상으로 한 연구가 확장되었다. 이러 한 측정 방법에서는 낮선상황실험과 같이 경미한 스트레스 상 황에서 애착 시스템이 작동한다는 가정을 하고 있지만, 스트 레스 상황에 있어서 차이를 보인다. 예를 들어, 낮선상황실험 은 격리를 통해 스트레스 상황을 유발하지만, 그림이나 인형 놀이에서는 격리 뿐 아니라 다치거나 아프거나 두려움이 느 껴지거나 엄마를 잃어버렸을때와 같은 다양한 스트레스 상황 을 제시하며 유아가 어떻게 반응하는지를 관찰한다는 점에 서 다르다. ASCT나 MSSB와 같은 인형놀이를 활용한 애착검 사는 유아들에게 친숙한 매체를 활용하여 상상놀이를 매개 로 자연스럽게 유아의 애착특성을 이끌어낼 수 있다는 장점이 있다. 하지만 검사상황에서 나타난 유아의 자기보고에 근거 한 평가 척도이므로, 가정과 같은 자연스러운 상황에서 나타 나는 애착관계를 얼마나 잘 반영하는지 검증되지 않았고, 성 인에 비해 검사환경에 영향을 받기 쉬운 유아에 의한 자기 보 고는 신뢰성이 떨어질 수 있다는 한계점을 지닌다. 이러한 한 계점을 극복하기 위한 노력으로 Bretherton 등(1990)은 표상 을 통한 애착 측정의 타당성을 증명하기 위해 행동의 관찰을 통해 측정된 애착유형과 애착표상간의 일치정도를 살펴보았 는데, 3세 유아를 대상으로 어머니와의 격리-재결합 장면에 서 유아를 관찰한 결과와 ASCT를 통해 측정한 애착 표상 간 의 비교를 통해 표상을 통한 애착 측정의 유용성을 보고하였 다. 또한 ASCT는 격리/재결합 상황에 대한 영아의 반응을 다 루는 낮선상황실험(Gloger-Tippelt, Gomille, König, \& Vetter, 2002; Solomon, George, \& DeJong, 1995)과 어머니의 성인애 착면접(Gloger-Tippelt et al., 2002; Miljkovitch, Pierrehumbert, Bretherton, \& Halfon, 2004)과 같은 다른 코딩체계를 가진 여 러 연구들에서도 교차 검증되었다. 이러한 연관성은 이야기 완성이 유아의 부모에 대한 내적실행모델을 반영한다는 가정 을 뒷받침하는 것으로 볼 수 있다.

국내에서는 2000년대 초부터 유아대상 애착표상 연구(Park $\&$ Kwon, 2005; J. S. Lee, 2001; Shin \& Lee, 2005)에서 ASCT의 타당성이 검토되기 시작했으며, 이후 애착표상과 사회정서능 력(Kim \& Jun,, 2008; Kwak, 2015; Seo, 2009; Hwang \& Bang, 2012), 애착표상과 문제행동(Baek \& Lee, 2004; Shim, 2013; H. Lee, 2004) 등의 연구에서 사용되어 왔다. ASCT를 사용하여 부와 모에 대한 애착표상을 측정한 연구(Seo, 2009)에서 안정 
애착 집단이 불안정 회피 집단 유아보다 친사회적행동이 높은 반면, 불안정 비조직집단 유아보다 외현화 행동점수가 낮았 다. 또한 안정애착 유아가 불안정 애착 유아보다 지도력과 유 능성이 높고 불안정성은 낮은 경향을 보인 반면(J. H. Kim \& Jun, 2008) 유아의 애착표상과 문제행동 간의 관련성에 대한 연구(Shim, 2013)에서는 안정애착 유아가 불안정 애착 유아보 다 문제행동 수준이 낮은 것으로 밝혀졌다.

Sroufe (1983)는 아동이 이전의 적응에 기초하여 환경에 상 호작용하게 되면서 자기 반복적인 순환을 유지하게 된다고 보 았는데, 저항적인 애착 유형을 가진 영아는 지속적으로 부모 의 주의를 끌기 위해 화내고 요구함으로써 부모의 반응을 끌 어내고 그러한 패턴이 반복됨으로 인해 매우 의존적이거나 충 동적인 성향을 가지게 된다고 한다. 반면에 회피애착을 형성 한 영아는 정서적인 지지가 필요한 상황에서도 정서적 지지 를 요구하지 않는 법을 배우게 되고 이를 지속함으로써 결국 자신의 감정을 억압하는 것과 거짓된 긍정적인 감정으로 대체 하는 것을 보일 수 있다고 한다. 실제, 영아기에 불안정 저항애 착으로 분류된 유아가 걸음마기에 더욱 투정을 부리고, 쉽게 좌절하는 경향을 보였으며(Fox \& Calkins, 1993), 4세에는 자 신감이 부족하고 독단적이었으며(Erikson, Sroufe, \& Egeland, 1985), 영아기에 불안정 회피애착을 형성한 유아에 대해 유 치원 교사들은 공격성, 사회적 고립, 학습에서의 비사회성이 있음을 보고하였다(LaFreniere \& Sroufe, 1985; Troy \& Sroufe, 1987). 이처럼 영아기에 측정한 불안정한 애착 패턴이 이후의 환경에 대한 다양한 역기능적인 적응형태로 나타나게 되는 연 구결과들이 꾸준히 발표된 데 비해 유아기의 애착 유형에 따 른 발달적 결과를 살펴본 연구는 부족한 편이다. 앞서 살펴보 았듯이 ASCT를 사용하여 취학전 유아의 애착표상을 평가하 고 발달적 결과와의 관련성을 규명하고자 하는 연구들이 이루 어져 왔으나, 일부 연구를 제외하고는 애착유형을 안정애착과 불안정애착 유형으로 구분하여 사회정서발달의 차이를 분석 함으로써(J. H. Kim \& Jun, 2008; Shim, 2013) 애착의 하위유형 간의 차이를 살펴보는 데 한계가 있다. 불안정한 애착을 형성 한 유아들이 안정애착 관계모델을 형성한 유아들에 비해 행동 문제를 일으킬 위험이 높은 것은 많은 연구들에서 밝혀져 왔 지만 불안정애착 유형 내에서의 차이를 규명한 연구는 드물 다. 발달적 민감기인 영유아기에 유아들의 개별 특성을 보다 세밀하게 이해하는 것은 이에 대한 보다 구체적인 개입을 가 능하게 하는 초석이 될 수 있다. 이에 본 연구에서는 불안정 회 피애착과 불안정 비조직애착 유형의 경우 애착의 발달적 결과 가 달리 나타날 수 있음을 가정하고 이를 구분하여 문제행동
과의 관련성을 분석해보고자 한다.

한편, ASCT를 사용한 선행연구의 대부분이 초기의 코딩지 침을 지속적으로 사용해오고 있는데, 애착유형을 안정 애착과 불안정 회피 애착, 불안정 비조직 애착으로 범주화하거나 유 형에 따른 안정성을 기준으로 점수화를 하는 방식으로 평정하 는 분석이 주를 이루었다. 유형화하는 코딩방식은 각 집단의 특성을 명확히 밝혀주지만 집단 내에서의 개별적인 특성을 살 펴보기는 어렵다. 또 애착안정성에 따른 코딩방식은 개인차는 확인할 수 있지만 애착유형 집단 간의 차이는 파악하기 힘들 다. 이러한 한계점을 고려하여 애착의 유형화에 따른 집단 간 특성 뿐 아니라 내러티브 내용 분석을 통해 같은 유형 내에서 의 특성을 보다 면밀히 살펴볼 필요가 있다.

따라서 본 연구는 ASCT를 사용하여 유아의 내러티브에 나 타난 유아의 이야기내용 분석 및 애착유형을 분류하고 문제행 동과의 관련성을 분석함으로써 유아기 애착특성에 따른 발달 적 결과를 알아보고자 한다. 유아의 애착표상과 문제행동과의 관련성에 초점을 둔 본 연구는 유아기 애착평가 도구에 대한 연구 및 임상현장에서 아동에 대한 이해와 부모상담을 위한 기초자료로 활용될 수 있는 것이다. 연구문제는 다음과 같다. 첫째, 내러티브에 의한 유아의 애착 표상의 내용과 유형은 어 떠한 경향을 보이는가? 둘째, 내러티브에 의한 유아의 애착표 상의 내용 및 유형과 문제행동 간의 관계는 어떠한가?

\section{연구방법}

\section{연구대상}

본 연구대상은 유아교육기관 만 4, 5세반에 재원중인 유아들 로 검사실시 당시(2017년 1-2월) 만 4-6세 생활연령인 유아 100 명으로, 성별은 남아가 42 명(42\%), 여아가 58명(58\%)이 다. 연령별로는 4 세아 $(M=56$ 개월 $) 31$ 명, 5 세아 $(M=67$ 개월 $)$ 54 명, 6 세아 $(M=74$ 개월) 15 명으로 만 5세 유아(54\%)가 전체 의 반 정도이고, 4 세아 $(31 \%), 6$ 세아 $(15 \%)$ 순이었다.

\section{연구도구}

\section{애착검사 및 평정}

애착검사도구 본 연구에서 유아의 애착표상을 측정하기 위해 Bretherton 등(1990)이 개발한 '애착 이야기 완성 과제 
(Attachment Story Completion Task [ASCT])'를 번안하여 J. S. Lee (2001)가 사용한 척도를 수정하여 이용하였다. ASCT를 실 시하기 위한 주요 도구는 작은 가족 인형으로, 처음 3 개의 이 야기를 위한 어머니, 아버지, 두 자녀(형제, 자매)와 나머지 2 개 이야기를 위한 도우미 아주머니 인형으로 구성된다.

ASCT는 1 개의 워밍업 이야기와 5 개의 애착관련 주제의 이 야기로 구성되며, 정해진 실시지침에 따라 시행된다. 먼저 검 사자는 유아에게 ASCT 도구를 소개하고 실시 절차를 이해할 수 있도록 생일파티에 관한 워밍업 이야기를 시작한다. 그 다 음 5개의 애착관련 주제의 이야기('물을 엎질렀어요', '무릎을 다쳤어요', '내 방에 괴물이 있어요', '부모님이 여행을 가셨어 요', '부모님이 돌아오셨어요')를 들려준다. 각 이야기는 유아 가 일상생활에서 부딪칠 수 있는 애착 관련 갈등이나 문제를 다루고 있다. 검사자는 표준화된 실시지침에 따라 각 주제의 이야기를 들려준 후, "다음에 어떤 일이 일어나는지 보여주고 이야기를 해주겠니?"하고 제안하며, 유아는 인형가족과 소품 을 사용하여 그 다음 이야기를 마치도록 한다.

애착표상의 평정 애착표상의 평정은 내용분석과 애착유형을 분류하는 방식으로 이루어졌다. 첫째, 유아의 내러티브에 대 한 내용분석은 Golby, Bretherton, Winn과 Page (1995)의 코딩 지침과 Rosenthal (1999)의 코딩지침을 근거로 실시되었다. 내 용분석은 긍정적 내용코드, 부정적 내용코드, 격리반응, 훈육 과 처벌, 비전형적 반응의 5 개의 범주로 구분되고 각각은 하위 요인을 가지고 있으며, 각 이야기에 해당하는 요인에 빈도를 체크하여 점수화하는 방식으로 평정하였다. 내용분석을 위한 코드는 처음 22 개였으며, 각 코드별로 평정을 실시한 결과, 전 체 빈도가 1 이하로 낮거나 코드 내용이 유사하여 보다 큰 상위 범주로 묶일 수 있는 코드들을 조정하여 최종적으로 5개 범주 14 개의 코드로 구성하였다. 구체적으로, 긍정적 코드(양육/공 감, 애정, 동료감, 자기신뢰), 부정적 내용코드(거절, 공격, 괴 물부정), 격리반응(격리불안, 조용한 격리반응, 긍정반응), 훈 육과 처벌(훈육과 처벌), 비전형적 반응(회피, 비전형적 사건 1 , 비전형적 사건2) 등으로 구성되는데, 하위코드의 정의와 세부 내용은 선행연구(Han \& Lee, 2017)를 참고할 수 있다.

둘째, 애착표상에 근거한 애착유형 분류는 Bretherton 등 (1990)의 코딩지침을 근거로 수정한 Golby 등(1995)의 코딩지 침과 Goodman, Andrews와 Jones (1992)의 코딩지침에 근거하 여 안정, 불안정 회피, 불안정 비조직 유형으로 분류하였으며, 기준에 부합하지 않는 일부 사례는 미분류로 하였다(J. S. Lee, 2001 재인용). 각 이야기에 대한 평정을 한 뒤, 5 개의 이야기
전체에 대하여 Bretherton 등(1990)의 분류기준에 근거하여 각 사례의 애착유형을 분류하였다. 안정애착은 모든 이야기에 대 해서 이야기의 주제를 일관성 있고 적절하게 해결하거나, 한 두 개의 이야기에 대해서 회피나 괴상한 반응을 보이는 경우 이다. 불안정 회피애착은 3 개 이상의 이야기에 대해서 강하게 방어적인 반응을 보이는 경우이다. 불안정 비조직 애착은 3 개 이상의 이야기에 대해서 이상하고 비조직적인 반응을 보인 경 우이다. 이러한 기준에 해당하지 않는 경우(예: 안정 이야기 2 개, 불안정 회피 이야기 2 개, 불안정 비조직 이야기 1개)에는 미분류된 사례로 처리하였다.

애착검사 실시는 훈련된 석사 대학원생들에 의해 수행되 었으며 평정은 아동학 전공 교수와 박사가 실시하였다. 연구 자들은 ASCT 도구를 수년간 사용해 본 경험이 있는 전공자로 서, 애착검사 실시를 위해서 검사자 3 인에게 검사의 내용과 실 시방법을 교육하고 모의검사와 피드백을 통한 사전 훈련을 실 시하였다. 검사자들은 유아 2명씩을 대상으로 예비검사를 실 시하여 다시 한번 검사내용에 대해 숙지하고 실시 시 유의사 항을 점검하였다. 유아의 애착표상에 관한 내용분석 및 유형 분류는 본 연구자들에 의해 수행되었다. 먼저 각 이야기에 대 한 내용 평정과 유형분류 기준에 대해 토의하고 숙지한 뒤, 각 자 전사본을 읽고 분석한 다음 차이가 있는 경우에 토의를 거 쳐 평정기준을 일치시키고자 노력하였다. 애착표상의 내용 분석 평정에서 두 평정자가 10 사례에 대해 각각 평정한 점수 를 가지고 관찰자간 신뢰도를 구한 결과(적률상관계수 $r=.81$ .92) 신뢰로운 것으로 나타났다. 내용분석 평정에 대해 재논 의를 한 뒤 아동학전공 박사 연구자가 최종 평정을 실시하였 다. 애착유형 분류는 두 평정자가 전체 사례를 각각 분류한 뒤 불일치하는 경우에 논의를 거쳐 동의된 유형으로 분류하였다.

\section{유아의 문제행동}

문제행동을 측정하기 위하여 Achenbach와 Rescorla (2000)가 개정하고 $\mathrm{Oh}$ 와 $\mathrm{Kim}$ (2010)이 한국판으로 번역하여 표준화 한 유아행동 평가척도 교사용(Caregiver-Teacher Report Form [C-TRF])을 사용하였다. 본 도구는 만 18 개월 만 5세의 영유 아를 대상으로 실시할 수 있으며, 검사는 영유아를 담당하거 나 잘 알고 있는 교육기관의 교사가 실시할 수 있도록 교사 보 고식 검사로 구성되어 있다. 본 척도는 문제행동 증후군 척도 와 DSM진단척도로 구성되어 있다. 문제행동 척도는 모두 7 개 하위 영역으로 구분되는데, 이는 정서적 반응성, 불안/우 울, 신체증상, 위축, 주의집중문제, 공격행동, 기타문제를 포 
함한다. DSM진단척도는 정서문제, 불안문제, 전반적 발달문 제, $\mathrm{ADHD}$, 반항행동 문제로 구분된다. 문항은 총 100 문항으 로 교사가 지난 2 개월을 기준으로 각 문항에 서술된 행동을 유 아가 보였는지를 판단하여 '전혀 해당되지 않는다(0점)' ' '가끔 그렇거나 그런 편이다(1점)', '자주 그런 일이 있거나 많이 그 렇다(2점)'의 3점 Likert척도로 응답한다. 본 연구에서의 신뢰 도 계수(Cronbach's $\alpha$ )는 .76 .94로 나타났다. 문항별 점수를 합친 원점수를 표준화 집단을 규준으로 한 $t$ 점수로 환산하여 통계분석에 사용하였다. 환산점수는 척도를 보급하는 (주)휴노 로 원점수를 보내어 산출하였다.

\section{연구절차}

본 연구는 연구 실시 이전에 전북대학교 연구윤리위원회의 승 인을 받은 후 진행되었다. 연구자는 연구 참여에 동의한 어린 이집(2개소)과 유치원(1개소)을 방문하여 원장에게 연구 목적 과 내용을 설명하고 가정통신문과 함께 각 가정에 연구 동의 서와 설명문을 배포하였다. 본 연구에 대한 연구 동의서에 서 명한 유아에게 애착검사를 실시하고 담임교사에게 설문조사 를 실시하였다. 애착 검사는 2017년 1월부터 2월 첫 주까지 진 행되었으며, 해당 어린이집에 검사자들이 방문하여 별도의 조 용한 교실에서 애착검사를 실시하였다. 소요시간은 유아별로 약 20 분 정도 걸렸으며, 검사를 마친 유아에 대해 담임교사에 게 유아행동 평가척도(C-TRF)를 배부하고 회수하였다. 유아 의 애착검사와 교사의 질문지 회수가 모두 이루어진 유아 100 명의 자료를 최종 분석 자료로 사용하였다.

\section{자료분석}

유아의 애착검사는 본 연구자들이 선행연구의 코딩지침에 근 거하여 각자 점수화와 분류를 한 뒤 토의를 거쳐 합의하에 점 수화와 분류화 작업을 수행하였다. 본 연구의 통계적 분석방 법은 다음과 같다. 먼저 주요 변수인 유아의 내러티브 하위 요 인 간의 관련성을 파악하기 위해 피어슨 적률상관분석을 실시 하였고, 문제행동의 일반적 경향을 살피기 위해 평균과 표준 편차를 산출하였다. 또한, 유아의 애착특성과 문제행동이 유 아의 성별에 따라 차이가 있는지 알아보기 위해 독립 $t$ 검증을 실시하였다. 유아의 내러티브 내용과 문제행동 간의 관련성 을 살펴보기 위해 적률상관분석을 실시하였으며, 유아의 애착 표상 유형에 따라 문제행동에 차이가 있는지 알아보기 위해 $F$ 검증을 실시하였다.

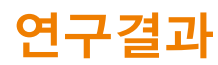

\section{내러티브에 의한 유아의 애착표상 내용과 유형}

\section{유아의 내러티브 내용}

ASCT에 나타난 유아의 반응 내용을 알아보기 위해 선행연구 (Golby et al., 1995; Rosenthal, 1999)의 코딩지침을 근거로 분석 하였다. 유아의 내러티브 내용은 5개 범주(긍정적 내용코드, 부정적 내용코드, 격리반응, 훈육과 처벌, 비전형적 반응) 22 개 하위 요인으로 분석되었으나 유사하거나 중복된 내용을 조 정하여 14 개 하위 요인으로 구성하였다. 그 결과 긍정적 내용 코드(양육/공감, 애정, 동료감, 자기신뢰), 부정적 내용코드(거 절, 공격, 괴물부정), 격리반응(격리불안, 조용한 격리반응, 긍 정반응), 훈육과 처벌(훈육/처벌), 비전형적 반응(회피, 비전형 적 사건1, 비전형적 사건2)등이 나타났다. 이렇게 선정된 14개 하위 요인 간의 관계를 알아보기 위해 피어슨의 상관관계분석 을 실시한 결과는 Table 1 과 같다.

Table 1에 제시된 바와 같이, 긍정적 내용코드 중 양육/공감 은 동료감 $(r=.36, p<.001)$, 조용한 격리반응 $(r=.47, p<.001)$, 재결합시의 긍정반응 $(r=.32, p<.001)$ 과 정적상관이 나타났 으나 애정, 자기신뢰, 격리불안과는 유의한 관련이 나타나지 않았다. 반면 부정적 내용코드 중 공격 $(r=-.24, p<.05)$ 및 괴 물부정 $(r=-.20, p<.05)$, 비전형적 반응 중 회피 $(r=-.64, p<$ $.01)$, 비전형적사건 $2(r=-.24, p<.01)$ 와 부적상관이 나타났다. 다음으로 애정 요인은 동료감 $(r=.26, p<.05)$, 재결합시의 긍 정반응 $(r=.47, p<.001)$ 과 정적상관, 비전형적사건 $2(r=-.20, p$ $<.05)$ 와 부적상관이 나타났다. 그러나 공감/애착 요인과 달리 부정적 내용코드 및 회피와는 유의한 관련이 나타나지 않았 다. 동료감 요인은 조용한 격리반응 $(r=.63, p<.001)$ 및 긍정 반응 $(r=.27, p<.001)$ 과 정적상관, 격리불안 $(r=-.40, p<.001)$ 및 회피 $(r=-.36, p<.001)$, 비전형적 사건 $1(r=-.25, p<.05)$, 비 전형적 사건 $2(r=-.24, p<.05)$ 과 부적상관이 나타났다. 긍정 적 내용코드 중 자기신뢰 요인은 다른 어떤 요인과도 유의한 상관관계가 나타나지 않았다. 다음으로, 부정적 내용코드 중 부모의 거절은 재결합시의 긍정반응과 부적상관 $(r=-.23, p<$ $.05)$ 이 있으며, 공격 및 괴물부정은 비전형적 사건2와 정적상 관 $(r=.46, p<.001 ; r=.28, p<.01)$ 이 나타났다. 격리불안은 비 전형적 반응과 유의한 상관이 나타나지 않은 반면, 조용한 격 리반응은 회피 $(r=-.44, p<.001)$, 비전형적 사건 $1 / 2(r=-.23, p$ $<.05 ; r=-.27, p<.01)$ 와 부적상관이 나타났다. 
Table 1

Correlation Statistics of the Content Codes

\begin{tabular}{|c|c|c|c|c|c|c|c|c|c|c|c|c|c|c|}
\hline & \multirow{2}{*}{\multicolumn{4}{|c|}{ Positive Content Codes }} & \multirow{2}{*}{\multicolumn{3}{|c|}{ Negative Content Codes }} & \multicolumn{7}{|c|}{ Discipline } \\
\hline & & & & & & & & Separatic & n-Reunic & n Code & \multirow{2}{*}{$\begin{array}{c}\text { Code } \\
11\end{array}$} & \multicolumn{3}{|c|}{ Atypical Codes } \\
\hline & 1 & 2 & 3 & 4 & 5 & 6 & 7 & 8 & 9 & 10 & & 12 & 13 & 14 \\
\hline 1 & - & & & & & & & & & & & & & \\
\hline 2 & .07 & - & & & & & & & & & & & & \\
\hline 3 & $.36^{* * *}$ & $.26^{*}$ & - & & & & & & & & & & & \\
\hline 4 & -.19 & -.14 & .06 & - & & & & & & & & & & \\
\hline 6 & $-.24^{*}$ & -.12 & -.18 & -.09 & -.05 & - & & & & & & & & \\
\hline 7 & $-.20^{*}$ & -.14 & -.12 & -.01 & $.29^{* *}$ & $.42^{* * *}$ & - & & & & & & & \\
\hline 8 & -.08 & -.04 & $-.40^{* * *}$ & -.01 & .06 & -.04 & .00 & - & & & & & & \\
\hline 9 & $.47^{* * *}$ & .15 & $.63^{* * *}$ & -.00 & -.03 & -.10 & -.01 & $-.64^{* * *}$ & - & & & & & \\
\hline 13 & -.17 & -.03 & $-.25^{*}$ & -.03 & -.02 & .06 & .00 & .21 & $-.23^{*}$ & -.05 & .01 & -.04 & - & \\
\hline 14 & $-.35^{* * *}$ & $-.20^{*}$ & $-.24^{*}$ & -.10 & -.13 & $.46^{* * *}$ & $.28^{* *}$ & .17 & $-.27^{* *}$ & $-.34^{* *}$ & .02 & -.11 & .09 & 一 \\
\hline
\end{tabular}

Note. 1 = nurturance/empathy; 2 = affection; 3 = companionship; $4=$ self-reliance; 5 = rejection; $6=$ aggression; $7=$ denial of monster; $8=$ separation anxiety; 9 = calm response to separation; $10=$ positive affection response; $11=$ discipline and punishment; $12=$ avoidance; $13=$ bizarre negative event (atypical event 1) 14 = disjointed event (atypical event 2).

${ }^{*} p<.05$. ${ }^{* *} p<.01{ }^{* * *} p<.001$.

Table 2

Types of Preschoolers' Attachment Representation

\begin{tabular}{|c|c|c|c|}
\hline Type & $\begin{array}{c}\text { Boys } \\
n(\%)\end{array}$ & $\begin{array}{c}\text { Girls } \\
n(\%)\end{array}$ & $\begin{array}{l}\text { Total } \\
n(\%)\end{array}$ \\
\hline Secure & $27(64.3)$ & $45(77.6)$ & $72(72.0)$ \\
\hline \multicolumn{4}{|l|}{ Insecure } \\
\hline Avoidant & $5(11.9)$ & $3(5.2)$ & $8(8.0)$ \\
\hline Disorganized & $4(9.5)$ & $6(10.3)$ & $10(10.0)$ \\
\hline Unclassified & $6(14.3)$ & $4(6.9)$ & $10(10.0)$ \\
\hline Total & $42(100.0)$ & $59(100.0)$ & $100(100.0)$ \\
\hline
\end{tabular}

\section{유아의 애착표상 유형에 따른 내러티브 반응}

내러티브에 근거한 유아의 애착표상 유형을 살펴보기 위해 Bretherton 등(1990)과 Goodman 등(1992)의 코딩지침을 사용 하여 안정 애착, 불안정 회피, 불안정 비조직 유형으로 분류하 였다. Table 2와 같이, 본 연구대상 유아의 애착유형의 분포는 안정 애착이 전체의 $72 \%$ 를 차지하였으며, 불안정 회피 애착 $8 \%$, 불안정 비조직 애착 $10 \%$ 로 분류되었다. 미분류는 $10 \%$ 로 나타났다. 유아의 성별 및 연령에 따라 애착유형의 차이가 있 는지를 분석한 결과, 통계적으로 유의한 차이가 나타나지 않
았다.

다음으로, 애착 유형의 내용적 특성을 살펴보기 위하여 애 착표상 유형에 따른 내용코드의 차이를 알아보았다. Table 3에 제시한 바와 같이, 안정 애착유형은 양육/공감, 동료감, 조용 한 격리반응, 재결합시의 긍정반응이 다른 유형에 비해 높게 나타났다. 불안정 회피애착유형은 회피반응이 가장 높은 반 면, 양육/공감, 동료감, 격리불안이 가장 낮은 것으로 나타났 다. 불안정 비조직애착유형은 괴상한 부정적인 내용(사건1)과 일관성 없고 맥락에서 벗어나는 내용(사건2)의 빈도가 가장 높았고 공격성과 분리불안도 높게 나타났다. 
Table 3

Differences in Content Codes by Attachment Representation Type

\begin{tabular}{|c|c|c|c|c|c|}
\hline Content codes Attachment types & $\begin{array}{l}\text { Secure } \\
(n=72) \\
M(S D)\end{array}$ & $\begin{array}{l}\text { Insecure } \\
\text { Avoidant } \\
(n=8) \\
M(S D)\end{array}$ & $\begin{array}{c}\text { Insecure } \\
\text { Disorganized } \\
(n=10) \\
M(S D)\end{array}$ & $\begin{array}{l}\text { Unclassified } \\
\qquad(n=10) \\
M(S D)\end{array}$ & $F$ \\
\hline Affection & $.37(.54)$ & $.00(.00)$ & $.00(.00)$ & $.40(.69)$ & 2.67 \\
\hline Companionship & $.66(.55) / \mathrm{a}$ & $.00(.00) / \mathrm{b}$ & $.00(.00) / \mathrm{b}$ & $.20(.42) / a b$ & $10.03^{* * *}$ \\
\hline Rejection & $.06(.25)$ & $.00(.00)$ & $.10(.31)$ & $.10(.31)$ & .28 \\
\hline Aggression & $.00(.00) / \mathrm{a}$ & $.00(.00) / \mathrm{a}$ & $.60(1.07) / \mathrm{b}$ & $.20(.42) / a b$ & $8.96^{* * *}$ \\
\hline Denial of Monster & $.00(.00) / \mathrm{a}$ & $.00(.00) / \mathrm{a}$ & $.20(.42) / a b$ & $.30(.48) / \mathrm{b}$ & $9.08^{* * *}$ \\
\hline Separation Anxiety & $.16(.37) / a b$ & $.00(.00) / \mathrm{a}$ & $.50(.52) / \mathrm{b}$ & $.30(.48) / a b$ & $3.06^{*}$ \\
\hline Avoidance & $.18(.42) / \mathrm{a}$ & $4.37(.91) / c$ & $.10(.31) / \mathrm{a}$ & $1.50(.97) / \mathrm{b}$ & $157.10^{* * *}$ \\
\hline Bizarre negative event & $.04(.20) / \mathrm{a}$ & $.00(.00) / \mathrm{a}$ & $1.20(1.39) / \mathrm{b}$ & $.40(.69) / \mathrm{a}$ & $16.10^{* * *}$ \\
\hline Disjointed event & $.08(.27) / \mathrm{a}$ & $.00(.00) / \mathrm{a}$ & $2.60(1.89) / \mathrm{b}$ & $.50(.70) / \mathrm{a}$ & $42.95^{* * *}$ \\
\hline
\end{tabular}

Note. Post-test: Scheffe.

${ }^{*} p<.05$. ${ }^{* * *} p<.001$.

\section{유아의 애착표상과 문제행동 관계}

\section{유아의 내러티브 내용과 문제행동 간의 관계}

ASCT에 대한 유아의 내러티브 내용과 문제행동간의 관계를 분석하기 위해 먼저 내용코드 14 개를 결과제시의 간명성을 위하여 유사한 특성을 중심으로 묶거나 삭제함으로써 정리 하였다. 내용코드 간에 상관관계가 높아서 범주가 유사한 특 성으로 나타난 것을 묶고(애정과 재결합시의 긍정반응을 애 정/긍정반응으로, 비전형적 사건 1 과 사건 2 를 비전형적 사건 으로), 요인 간에 상관관계가 없거나 매우 낮게 나타난 요인들 (자기신뢰, 괴물부정, 훈육처벌)은 삭제하였다. 정리된 총 9 개 의 내용코드와 유아의 문제행동과의 상관관계를 분석한 결과 는 Table 4와 같다.

내러티브 내용에서 회피 점수가 낮을수록 $(r=-.20, p<.05)$, 비조직 사건 점수가 높을수록 $(r=.34, p<.01)$ 공격행동 점수 가 높고, 비조직 사건 점수가 높을수록 $(r=.25, p<.05)$ 외현화 문제행동 점수가 높은 것으로 나타났다. 또한 DSM 진단척도 별 하위척도에서도 비조직 사건의 점수가 높을수록 $(r=.34, p$ <.05) 반항행동 점수가 높은 것으로 나타났다.

\section{유아의 애착표상 유형에 따른 문제행동의 차이}

유아의 애착표상 유형에 따른 문제행동의 차이를 분석하기 위 해 일원분산분석을 실시한 결과는 Table 5 와 같다. 분석 결과, 문제행동총점 $(F=2.85, p<.05)$ 과 외현화 문제행동 $(F=4.07, p$ $<.01)$ 에서 통계적으로 유의한 차이가 나타났다. 구체적으로, 외현화 행동문제 중 유아의 공격행동 $(F=6.74, p<.01)$ 에서 유의한 차이가 있었다. 사후검증 결과, 불안정 비조직애착유 형이 다른 유형에 비해 공격성 점수가 유의하게 높은 것으로 나타났다. DSM 진단척도에서도 반항행동문제에서 애착유형 간의 차이가 통계적으로 유의하였으며 $(F=3.69, p<.05)$ 사후 분석 결과, 불안정 비조직유형의 점수가 나머지 유형에 비해 높은 것으로 분석되었다.

\section{논의 및 결론}

본 연구는 내러티브를 통한 유아의 애착특성을 내러티브 내용 분석과 애착유형을 통해 살펴보고 문제행동과의 관련성을 살 펴보았다. 분 연구의 주요 결과와 논의를 살펴보면 다음과 같 다. 
Table 4

Correlations Between Attachment Representation Contents and Problem Behaviors

\begin{tabular}{|c|c|c|c|c|c|c|c|c|c|}
\hline & 1 & 2 & 3 & 4 & 5 & 6 & 7 & 8 & 9 \\
\hline \multicolumn{10}{|l|}{ Internalizing scales } \\
\hline Emotional responsiveness & .06 & -.15 & .01 & -.03 & .16 & -.09 & .14 & -.08 & -.04 \\
\hline Somatic symptoms & .13 & .06 & .11 & -.16 & -.06 & -.11 & .14 & -.09 & -.02 \\
\hline Withdrawn & -.10 & -.15 & .04 & .02 & .14 & -.02 & .05 & .05 & .04 \\
\hline Attention problem & .03 & -.18 & -.03 & -.03 & .11 & -.07 & .12 & -.07 & .16 \\
\hline Aggressive behavior & .03 & -.10 & -.13 & .09 & .14 & -.03 & .06 & $-.20^{*}$ & $.34^{* *}$ \\
\hline Other problem & .02 & -.15 & -.12 & .06 & .16 & -.05 & .10 & -.09 & .16 \\
\hline Internalizing problems & .03 & -.07 & .07 & -.14 & .07 & -.13 & .15 & -.04 & -.03 \\
\hline Emotion problem & .04 & -.06 & -.04 & .01 & .13 & .04 & .02 & -.05 & .05 \\
\hline Anxiety & .01 & -.16 & .03 & -.09 & -.09 & -.06 & .05 & .06 & -.09 \\
\hline Developmental problem & -.02 & -.12 & .07 & -.03 & .07 & -.15 & .15 & .06 & -.08 \\
\hline $\mathrm{ADHD}$ & .04 & -.15 & -.08 & .01 & .13 & -.07 & .13 & -.13 & .18 \\
\hline ODD & -.01 & -.09 & -.09 & .00 & .01 & -.01 & .06 & -.16 & $.28^{* *}$ \\
\hline
\end{tabular}

Note. 1 = nurturance/empathy; 2 = affection/positive affection; 3 = companionship; 4 = rejection; 5 = aggression; 6 = separation anxiety; 7 $=$ calm response to separation; $8=$ avoidance; $9=$ atypical event.

${ }^{*} p<.05 .{ }^{* *} p<.01$.

첫째, 유아의 내러티브 내용분석을 위해 이야기의 핵심 주 제에 따라 긍정적 내용코드, 부정적 내용코드, 격리반응, 훈 육/처벌, 비전형적 반응의 5 개 범주 14 개 하위 요인으로 점수 화하고 각 하위요인 간의 관련성을 파악한 결과, 긍정적 내용 코드는 부정적 내용코드, 비전형적 반응과 부적상관이 나타났 으며, 부정적 내용코드는 비전형적 내용과 유의한 관련이 나 타나는 등 내러티브 내용들 간에 일관성있는 관계가 있음을 확인하였다. 즉, 스트레스 상황에서 부모의 양육적이고 공감 적인 반응이 높을수록 부모와의 격리시 불안이 적고 재결합 장면에서 부모에게 긍정적인 반응을 보이는 것으로 연결해 볼 수 있다. 이러한 결과는 유아의 고통과 두려움에 대한 부모의 양육적이고 공감적인 반응 및 애정요인이 안정애착의 핵심 요 소라는 점을 지지하는 결과로 해석된다. 부모 외에 타인과의 친사회적 행동을 의미하는 동료감 요인은 격리불안 및 긍정반 응, 비전형 코드와의 관련성이 나타났다. 즉, 타인과의 친사회 적 행동이 높을수록 격리불안이 낮고 재결합시 부모에게 긍정 적인 반응을 보이며, 회피 및 비전형적 반응이 낮음을 알 수 있 다. 마지막으로, 긍정적 코드 중 자기신뢰는 부정적 코드 및 비
전형적 반응뿐 아니라, 긍정적 내용코드의 다른 요인들과도 상관관계가 나타나지 않았다. 자기신뢰 요인은 애착유형 분석 에 관련된 다른 내용코드들과는 별도로 기능하는 것으로 보 여, 애착유형 분석 시 의미있는 지표로 해석하는데 한계가 있 을 것으로 생각된다. 아동이 주도적으로 문제를 해결하는 독 립적이고 자율적인 행동은 아동의 활발하고 적극적인 태도와 같은 기질과 관련이 있을 것으로 추측된다.

다음으로, 부정적 내용코드 중 부모의 거절은 재결합시의 긍정반응과 부적상관이 있으며, 공격 및 괴물부정은 비전형 적 사건 2 와 정적상관이 나타났다. 즉 유아가 도움과 관심을 원 하지만 부모의 거절당할 경우 부모에 대한 유아의 긍정반응이 낮고, 부정적 내용이 많을수록 이야기내용이 괴상하고 비조직 적이며, 일관성이 없고 맥락에서 벗어나는 반응을 보일 가능 성이 높은 경향을 보였다. 격리불안은 비전형적 반응과 상관 이 나타나지 않은 반면, 조용한 격리반응은 회피, 비전형적 사 건 $1 / 2$ 와 부적상관이 나타났다. 즉, 격리장면에서 불안을 보이 지 않을수록 회피 및 비전형적 반응이 낮은 경향을 보였다. 요 약하면, 유아의 내러티브 하위요소간의 관계를 분석해본 결 
Table 5

Differences in Problem Behaviors According to Attachment Representation Type

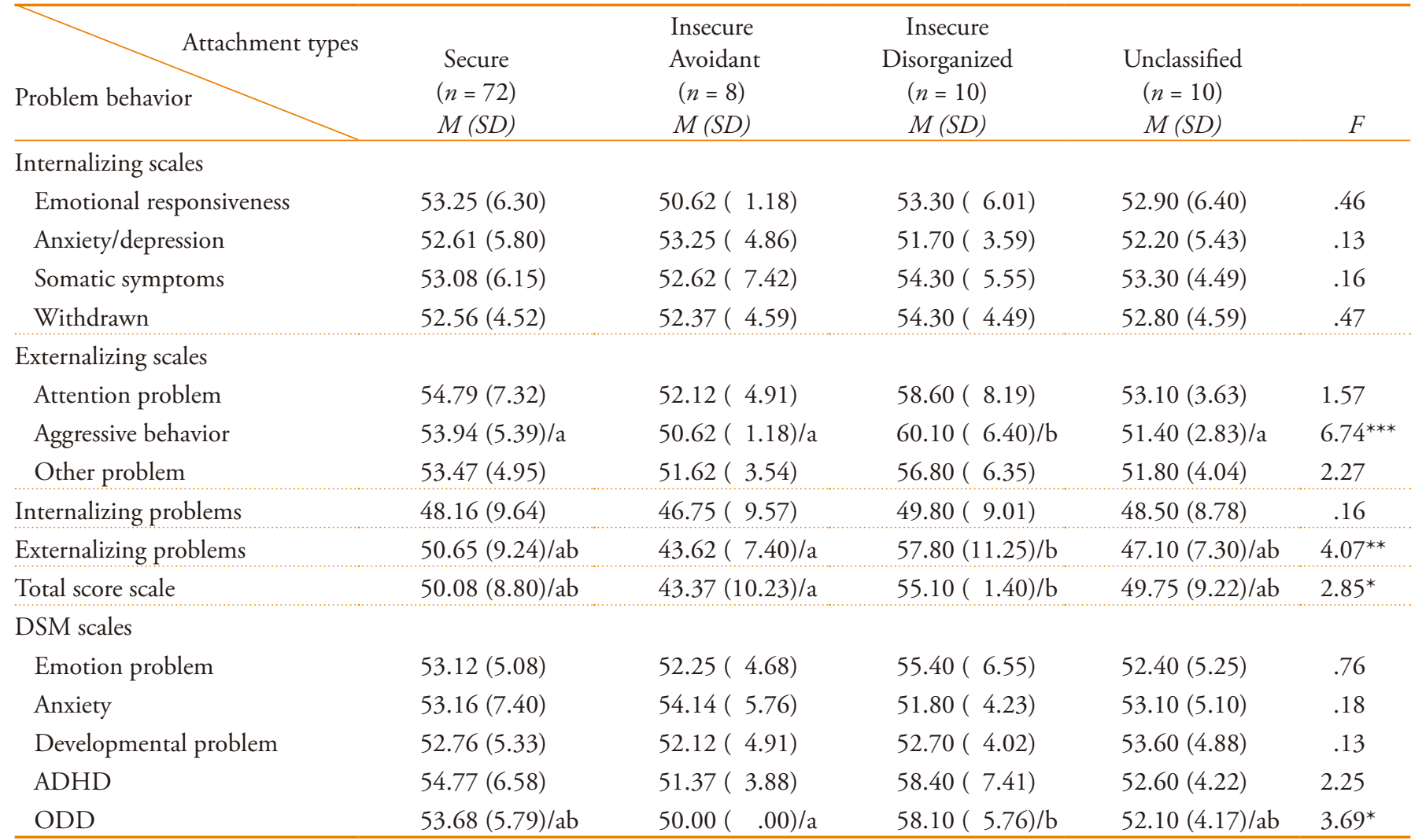

Note. Post-test: Scheffe.

${ }^{*} p<.05 .{ }^{* *} p<.01 .{ }^{* * *} p<.001$.

과, 긍정적인 내용코드 중 양육/공감, 애정, 동료감 요인은 낮 은 격리불안과 긍정적인 재결합반응, 부정적 내용 및 비전형 적 반응과 부적상관이 나타나 안정된 애착반응의 핵심적인 요 소임을 알 수 있다. 또한 격리장면에서 불안반응을 보이지 않 을수록 회피와 비전형적 반응이 낮은 경향을 보이는 반면, 부 정적인 내용이 많을수록 비조직적이며 일관성이 없고 맥락이 맞지 않는 사건이 나타나는 등, 대체로 유아의 내러티브 하위 요소 주제 간에 일관성이 발견되었다.

둘째, 본 연구대상 유아의 애착표상 유형은 안정애착이 전 체의 $72 \%$ 를 차지하였으며, 불안정 회피 $8 \%$, 불안정 비조직 $10 \%$ 로 분류되었다. 미분류는 $10 \%$ 로 나타났다. 연구대상 유 아의 성별과 연령에 다른 차이는 유의하지 않았다. ASCT를 사용한 국내 선행연구와 비교하면, 안정애착의 비율이 Kang 과 Park (2012)의 연구에서 54.3\%, Shim (2013)의 연구에서 62\%, Hwang과 Bang (2012)의 연구에서는 69.9\%로 나타났으 며, $\operatorname{Seo}(2015)$ 의 연구에서는 부와 모에게 모두 안정애착을 보 인 유아는 $64 \%$ 이고, 부/모 모두에게 불안정 애착을 형성한 유
아는 $13.5 \%$, 부 안정/ 모 불안(13.0\%), 모 안정, 부 불안(9.5\%) 으로 보고되었다. 이상의 연구들을 고려할 때 본 연구대상 유 아의 안정애착의 비율이 다소 높게 나타났다고 볼 수 있다. 그 러나 4세 유아를 대상으로 한 Kwak (2005)의 연구에서는 매우 안정(41.1\%)과 안정(33. $8 \%$ )의 비율이 $74.9 \%$ 로 보고되는 등, 안정애착의 비율은 연구에 따라 다소 차이가 있다. 본 연구의 대상은 맞벌이 부모가 많은 직장어린이집과 함께 전업주부 비 율이 높은 유치원이 연구대상이었으며 부모들의 동의가 이루 어진 경우에 한해 연구대상으로 선정되었기에 다소 안정애착 비율이 높아진 것으로 보인다. 각 연구마다 대상유아의 선별 과정에 따라 애착유형의 분포는 다소간 차이가 나타날 것으로 생각되나, 다른 한편 애착유형 분류방식에서의 차이 역시 영 향을 미칠 가능성이 있다.

애착유형에 따라 내러티브 내용에 차이가 있는지 살펴본 결과에서는 유형 간에 분명한 차이를 보였는데, 안정 애착유 형에서 양육/공감, 동료감과 같은 긍정적 내용코드의 반응이 높게 나타난 반면, 회피 애착유형은 회피반응이 높고, 비조직 
애착유형은 괴상하고 부정적인 내용이나 맥락에서 벗어나는 내용과 같은 비전형적 반응들의 빈도가 가장 높았다. 낯선상 황 실험과 같은 애착연구에서 중요하게 살펴보는 격리-재결 합 장면과 관련되는 격리-재결합코드에서는 안정 애착유형이 조용한 격리반응과 재결합시의 긍정반응이 높게 나타난 반면 비조직 애착유형은 격리불안이 높게 나타났다. 이러한 결과는 유아의 애착유형 분류에 있어서 내러티브 내용에 따른 분석의 유용성을 재입증해주며 애착유형에 따른 주요 내용코드를 확 인시켜주었다는데 의의가 있다.

셋째, ASCT에 대한 유아의 내러티브 내용과 문제행동 간의 관계를 분석한 결과, 비조직 사건 점수가 높을수록 공격적 행 동과 같은 외현화 행동점수가 높아지며, 특히 비조직 사건 점 수는 공격성 및 반항행동점수와의 유의한 정적상관이 나타났 다. 즉 유아가 애착관련 주제에 대하여 비조직적인 반응을 많 이 보고할수록 공격성과 반항 등 외현화된 행동 점수가 높아 지는 경향이 있음을 알 수 있다. 이러한 결과는 애착 검사를 통 해 드러나는 유아의 내러티브 내용이 유아의 사회정서적 발달 의 결과와 관련되므로 내용을 보다 구체적으로 분석해야 함을 시사한다.

한편, 유아의 내러티브 내용 중 회피 내용은 공격행동 점수 와 부적상관으로 나타나 회피내용을 보고할수록 공격행동이 낮은 것으로 나타났다. 이러한 결과는 유아의 회피적 성향이 공격행동을 감소시킨다는 발달적 결과로 해석하기보다는 특 정형태로의 적응의 모습을 보여주는 것으로 추측해볼 수 있 다. Sroufe (1983)는 불안정 회피적인 애착을 형성한 영아는 정 서적인 지지가 필요한 때에도 정서적 지지를 요구하지 않는 법을 배우게 됨에 따라 이후에 다른 사람들과도 정서적인 격 리나 적대감을 유지하게 되며, 자신의 감정을 억압하는 것과 거짓된 긍정적인 감정으로 대체하는 것을 배우게 된다고 하였 다. 이러한 회피적 성향의 유아가 교사에게 순응적이고 긍정 적으로 비춰져 오히려 다른 유아보다 덜 공격적인 것으로 평 가된 것으로 보인다. 선행연구(H.-H. Kim, 2008)에서는 유아 의 내러티브의 회피적 반응의 빈도와 문제행동과의 관계를 분 석하였는데, 회피적 반응이 많을수록 공격적 · 과잉행동이 많 고 친사회성이 낮게 나타나 본 연구와는 상반된 결과를 보였 다. 연구별로 코딩과 분석 방법에 차이가 있으므로 직접적인 비교는 어렵지만 추후 회피성향의 정도에 따른 발달적 결과의 차이를 살펴보는 것이 필요해 보인다.

그 밖에 유아의 내러티브 내용에서 양육/공감능력, 애정, 동료감과 같이, 자녀에 대한 부모의 양육적 돌봄과 공감, 애정 표현과 같은 긍정적 주제와 유아의 문제행동 간에 유의한 관
련성이 나타나지 않았다. 이는 모와의 친밀한 관계 등 긍정적 인 이야기 반응을 보인 유아가 사회적 유능성이 높다는 연구 (Page, 1998)와는 다소 거리가 있다. 이러한 결과는 애착 관련 주제에 대한 본 연구대상 유아의 반응내용이 다소 단순하고 제한적이어서 해당 범주의 빈도수가 높지 않았기 때문으로 생 각된다.

넷째, 애착유형에 따른 문제행동 분석 결과, 불안정 비조직 유형이 나머지 유형(안정, 회피, 미분류)보다 외현화 문제행 동 수준이 높으며, 특히 공격성 및 반항행동문제가 높게 나타 났다. 즉 다소 혼란스럽고 일관적이지 않은 행동패턴을 보이 는 불안정 비조직 애착유형의 문제행동 수준이 상대적으로 높 게 나타난 결과로 볼 수 있다. 이러한 결과는 안정애착 집단이 불안정 비조직애착 집단 유아보다 외현화 행동문제가 높으며 (Seo, 2009; J. S. Lee, 2001) 안정애착 집단이 불안정애착 집단 보다 행동문제 수준이 높다는 결과(Shim, 2013)를 지지한다. 부모와 안정적인 애착관계를 형성할 경우 유아는 주양육자에 대한 애정적이고 지지적인 내적실행모델을 발달시키며, 이를 통해 자신과 타인에 대한 긍정적인 정서와 기대를 형성할 수 있다. 반면, 불안정 비조직애착 집단의 경우 유아는 거부적.통 제적인 양육을 경험하며 부모의 도움과 위로를 얻지 못하고 부정적인 내적실행모델을 형성함으로써 부정적 정서와 문제 행동을 나타낼 수 있다. 불안정 비조직 집단의 유아는 안정애 착 및 불안정 회피애착 집단에 비해 자기정서인식과 조절능력 이 상대적으로 낮다는 보고(Seo, 2009)를 고려할 때, 불안정 비 조직 애착집단은 자신의 정서를 이해하고 그 이해를 바탕으로 정서를 조절할 수 있는 능력이 상대적으로 부족하며, 이로 인 해 외현화된 문제행동이 높아질 수 있을 것으로 보인다. 한편, 본 연구에서 내재화 문제행동에서는 애착유형간 차이가 유의 하지 않았다. 선행연구들에서도 애착과 내재화 문제행동간 의 관계를 밝힌 여러 연구들(Allen, Moore, Kuperminc, \& Bell, 1998; Buist, Dekovic, \& van Aken, 2004; Ronnlund \& Karlsson, 2006)이 있는 반면, 애착안정성과 내면화 문제와는 유의미 한 상관이 나타나지 않았다는 연구(Moss, Rousseau, Parent, Stlaurent, \& Saintonge, 1998)도 있어 이들 변인간의 관련성에 대 한 결과는 일치하지 않고 있다. 외현화 문제가 두드러지게 드 러나는 불안정 비조직 애착유형에 비해 불안정 회피애착유형 의 유아는 주양육자에 대한 거절감을 외부로 표현하지 않거나 혼자놀이에 몰입하는 등의 방어전략을 사용할 수 있으므로 외 현화 문제행동이 다소 낮게 평가될 가능성이 있을 것으로 사 료된다.

본 연구는 유아기 애착표상을 밝히기 위하여 애착검사도구 
인 ASCT를 사용하여 내러티브 내용과 유형분석을 실시함으 로써 보다 정교하고 체계적인 양적 및 질적 분석을 시도하였 다는데 의의가 있다. 또한 애착표상의 내용 및 유형과 유아의 문제행동과의 관련성을 분석하여 유아의 애착유형에 따라 문 제행동의 일부 하위영역(공격성, 반행행동문제)에 차이가 있 음을 밝혔다. 특히 애착유형 집단 중에서 비조직 애착유형이 나머지 집단(안정, 회피집단)보다 유의하게 문제행동 점수가 높은 것으로 나타났다. 본 연구는 유아의 긍정적인 사회 - 정서 발달을 도모하기 위한 부모와의 안정적인 애착형성의 중요성 을 재확인하였으며, 특히 불안정 비조직 애착 유아와 부모들 에 대한 관심과 개입의 필요성을 제기한다.

본 연구는 일부 지역의 유아들을 대상으로 하였기에 연구 결과를 일반화하는데 한계가 있다. 또한 유아의 애착표상과 문제행동과의 관련성을 분석하였는데, 애착과 사회정서 발달 간의 관련성을 폭넓게 규명하기 위해서는 문제행동 외에 다양 한 평가도구를 포함한 연구가 이루어질 필요가 있다. 또한 유 아기 애착평가 도구로서의 ASCT의 타당도를 보완하기 위해 애착관련 주제의 새로운 이야기를 보완하고 코딩지침을 정교 하게 수정·보완하는 등의 지속적인 노력이 필요하다고 본다. 이러한 제한점에도 불구하고 본 연구는 내러티브를 통한 유 아의 애착표상을 살펴보고, 애착표상과 문제행동 간의 관계를 분석함으로써 유아기의 정신건강과 부모상담에 도움이 되는 기초자료를 제공한데 의의가 있다.

\section{Notes}

This article was presented at the 8th International Conference of the Panel Study on Korean Children.

\section{Conflict of Interest}

No potential conflict of interest relevant to this article was reported.

\section{References}

\section{In English}

Achenbach, T. M., \& Rescorla, L. A. (2000). Manual for the ASEBA preschool forms \& profiles. Burlington, VT: University of Vermont, Research Center for Children, Youth, \& Families.

Ainsworth, M. D. S. (1969). Object relations, dependency and attachment: A theoretical review of the infant-mother relationships. Child Development, 40(4), 969-1025.

Ainsworth, M. D. S., Bell, S. M., \& Stayton, D. J. (1971). Individual difference in strange situation behavior of one-year-olds. In H. R. Schaffer (Ed.), The origins of human social relations (pp. 17-57). London: Academic Press.

Ainsworth. M. D. S., Blehar, M. C., Waters. E., \& Wall. S. N. (1978). Patterns of attachment: A psychological study of the strange situation. Hillsdale. NJ: Erlbaum.

Allen, J. P., Moore, C., Kuperminc, G., \& Bell, K. (1998). Attachment and adolescent psychosocial functioning. Child Development, 69(5), 1406-1419. doi:10.2307/1132274

Bowlby, J. (1980). Attachment and loss (Vol. 3). New York: Basic Books.

Bowlby, J. (2014). A secure base: Clinical application of attachment theory (Kim, S., Kang, Y., \& Kang, M.). Seoul: Hakjisa. (Original work published 1988.)

Bretherton, I. (1985). Attachment theory: Retrospect and prospect. In I. Bretherton and E. Waters (Eds.), Growing point of attachment theory and research. Monographs of the Society for Research in Child Development, 50(1-2, Serial No. 209). Chicago, IL: University of Chicago Press.

Bretherton, I., Ridgeway, D., \& Cassidy, J. (1990). Assessing internal working models of the attachment relationships: An attachment story completion task for 3-year-olds. In M. T. Greenberg, D. Cicchetti, and E. M. Cummings, (Eds.), Attachment in the preschool years: Theory, research, and intervention (pp. 273308). Chicago, IL: University of Chicago Press.

Buist, K. 1., Dekovic, M., Meeus, W., \& van Aken, M. G. (2004). The reciprocal relationship between early adolescent attachment and internalizing and externalizing problem behaviour. Journal of Adolescence, 27(3), 251-266. doi:10.1016/j.adolescence.2003.11.012

DeMulder, E. K. Denham, S., Schmidt, M., \& Mitchell, J. (2000). Q-Sort assessment of attachment security during the preschool years: Links from home to school. Developmental Psychology, 36(2), 274-282. doi:10.1037//0012-1649.36.2.274

Erickson, M. F., Sroufe, L. A. \& Egeland, B. (1985). The relationship between quality of attachment and behavior problems in preschool in a high risk sample. A. B. Smuts \& J. W. Hagen (Eds.), History and research in the child development, Monographs of the Society for Research in Child Development, 50, (4-5, Serial No. 211).

Fox, N. A., \& Calkins, S. D. (1993). Pathways to aggression and social withdrawal: Interactions among temperament, attachment, and regulation. In K. H. Rubin \& J. Asendorpf(Eds.), Social withdrawal, inhibition, and shyness in childhood(pp. 81-100). 
Hillsdale, NJ: Erlbaum.

Gloger-Tippelt, G., Gomille, B., König, L., \& Vetter, J. (2002). Attachment representations in 6-year-olds: Related longitudinally to the quality of attachment in infancy and mothers'attachment representations. Attachment \& Human Development, 4(3), 318-339. doi:10.1080/14616730210167221

Golby, B., Bretherton, I., Winn, L., \& Page, T. (1995). Coding Manual for the Attachment Story Completion Task. Unpublished manuscript. Madison, WI: University of Wisconsin.

Goodman, G., Andrews, T., \& Jones, S. (1992). Revised administration and coding guidelines for the attachment story-completion task. Unpublished manuscript, Columbia University, Barnard College. New York.

LaFreniere, P., \& Sroufe, L. A. (1985). Profiles of peer competence in the preschool: Interrelations between measures, influence of social ecology, and relation to attachment history. Developmental Psychology, 21(1), 56-69. doi:10.1037/00121649.21.1.56

Miljkovitch, R., Pierrehumbert, B., Bretherton, I., \& Halfon, O. (2004). Associations between parental and child attachment representations. Attachment \& Human Development, 6(3), 305-325. doi:10.1080/14616730412331281557

Moss, E. Rousseau, D. Parent, S. St-Laurent, D. Saintonge, J. (1998). Correlates of attachment at school age: Maternal reported stress, mother-child interaction, and behavior problems. Child development, 69(5), 1390-1405. doi:10.2307/1132273

Page, T. F. (1998). Linkages between children's narrative representations of families and social competence of child-care settings (Vol. 2). University of Wisconsin-Madison.

Ronnlund, M., \& Karlsson, E. (2006). The relation between dimensions of attachment and internalizing or externalizing problems during adolescence. The Journal of Genetic Psychology, 167(1), 47-63. doi:10.3200/GNTP.167.1.47-63

Rosenthal, R. J. (1999). Young children's representations of self and parents: Are they related to experiences with mothers and fathers? (Unpublished doctoral dissertation). University of Wisconsin-Madison.

Shaw, D. S., Keenan, K., Vondra, J. I., Delliquadri, E., \& Giovannelli, J. (1997). Antecedents of preschool children's internalizing problems: A longitudinal study of low-income families. American Academy of Child and Adolescent Psychiatry, 36(12), 1760-1767. doi:10.1097/00004583-19971200000025

Slough, N. M., \& Greenberg, M. T. (1990). Five-year-olds' representations of separation from parents: Responses from the perspective of self and other. New Directions for Child Development, 1990(48), 67-84. doi:10.1002/cd.23219904806

Solomon, J., George, C., \& DeJong, A. (1995). Children classified as controlling at age six: Evidence of disorganized representational strategies and aggression at home and school. Development and
Psychopathology, 7, 447-464. doi:10.1017/S0954579400006623

Sroufe, L. A. (1983). Infant-caregiver attachment and patterns of adaptation in the preschool: The roots of competence and maladaptation. In M. Perlmutter(Ed.), Minnesota Symposia in child Psychology(Vol. 16, pp. 41-83). Hillsdale, NJ: Lawrence Erlbaum Associates.

Sroufe, L. A., Schork, E., Motti, E., Lawroski, N., \& LaFreniere, P. (1984). The role of affect in social competence. In C. Izard, G. Kagan, \& R. Zajonc (Eds.), Emotion, cognition and behavior (pp. 289-319). New York: Plenum Press.

Troy, M., \& Sroufe, L. A. (1987). Victimization among preschoolers: Role of attachment relationship history. Journal of the American Academy of Child and Adolescent Psychiatry, 26, 166-172. doi:10.1097/00004583-198703000-00007

Vershueran, K., \& Marcoen, A. (1999). Representation of self and socioemotional competence in kindergartners: Differential and combined effects of attachment to mother and father. Child Development, 67(1), 183-201. Retrieved from https://www.jstor. org/stable/1132023

Waters, E., \& Deane, K. E. (1985). Defining and assessing individual differences in attachment relationships: Q-methodology and the organization of behavior in infancy and early childhood. Monographs of Society for Research in Child Development, 50(1-2), 41-65. doi:10.1111/1540-5834.ep11889952

\section{In Korean}

Baek, J., \& Lee. J. (2004). The relation between children's attachment, self-perception, and behavior problems. The Journal of Korea Open Association for Early Childhood Education, 9(3), 149168.

Han, J., \& Lee, J. S. (2017). Analysis of characteristics and types of attachment representation through young children's narratives. The Korean Journal of the Human Development, 24(4), 91107. doi:10.15284/kjhd.2017.24.4.91

Hwang, S.-Y., \& Bang, H.-J. (2012). The effects of attachment and temperament on the emotional and social competence of children. The Korean Journal of the Human Development, 19(3), 147-165.

Kang, I.-S., \& Park, H.-K.(2012). A study of the correspondence analysis on child-parent attachment and child's popularity: Focus on sociometric popularity and perceived popularity. The Journal of Korea Open Association for Early Childhood Education, $17(5), 381-402$.

Kim H.-H.(2008). The relations between preschool children's representation of attachment and their relationship to teachers, social skill, and behavior problems (Master's thesis). Retrieved from http://www.riss.kr/link?id=T11297084/

Kim, J. H., \& Jun, Y. H. (2008). The relationships among young children's representation of attachment, peer popularity, and 
social competence. Journal of Early Childhood Education. $17(2), 25-43$.

Gwak, Y. H. (2015). A path analysis of the relationship between children's attachment, self-concept, and social intelligence (Doctoral dissertation). Retrieved from http://www.riss.kr/ link?id=T13652233/

Lee, H. (2004). The relationship between MSSB narratives and behavior problems in 4-years-old boys (Master's thesis). Retrieved from http://www.riss.kr/link?id=T9711153/

Lee, J. S. (2001). Preschool children's representation of attachment: Associations with teacher-child relationship and social competence (Doctoral dissertation). Retrieved from http:// www.riss.kr/link?id=T8650314/

Lee, S. H., \& Kim, S. R. (1996). Child-parent attachment and social competence. Korean Journal of Child Studies, 17(1), 87-100.

Oh, K. J., \& Kim, Y. A. (2010). The Korean version of the Child Behavior Checklist(CBCL)-TRF 1.5-5. Seoul: Huno.

Park, K. J., \& Kwon, Y. H. (2005). Attachment representation of preschool children: Links to attachment security and motherchild interaction behavior. Korean Journal of Child Studies, 24(6), 247-262.

Seo, M.-W. (2009). Concordance between the representation of attachment to father and mother and cognitive, social, and emotional competence of children (Doctoral dissertation). Retrieved from http://www.riss.kr/link?id=T11731057/

Shim, M. K. (2013). A study on preschoolers' problem behavior, leadership, social perspective-taking ability according to attachment stability. The Journal of Play Therapy, 17(3), 4155.

Shin, H. W., \& Lee, Y. (2005). The relationship between attachment behaviors and narrative representations about mothers by 3 and 4 year-old children. Korean Journal of Child Studies, 26(6), 89-110.

\section{ORCID}

Jin Suk Lee http://orcid.org/0000-0003-2681-0979

Jihyeon Han http://orcid.org/0000-0003-0805-7055

Received February 28, 2018

Revision received March 29, 2018

Accepted April 7, 2018 